\title{
Real Estate's 21st Century Grand Challenges: The Big Issues and Project Management's Role
}

\author{
Andrew Edkins $^{1 *}$, Yolande Barnes ${ }^{2}$, Andrew Grainger $^{3}$, and Paul Chinowsky ${ }^{4}$
}

\begin{abstract}
This paper focuses on what real estate comprises, its forms of value in the 21 st century and project management's role and potential in strategic and front-end issues. The broad definition of real estate used is examined through the lens of current challenges and foreseeable major change drivers. Critical realism and engaged scholarship are employed to consider a wide range of primary data generated from multiple practitioner engagement exercises. This process has revealed eight themes that relate to real estate in the 21st century: 1. Digital Disruption, 2. Health and Wellbeing, 3. Learning Environments, 4. Accessible and Affordable Housing, 5. Beyond Placemaking, 6. Resilience, 7. Infrastructure Interfaces, 8. Community Inclusion. The value proposition of this paper is to illustrate the relevance and contribution of project management to real estate and to consider the implications from the proposed set of eight highly relevant, cross-cutting themes. Within the six principal implications identified, we show how project management in the 21 st century needs to be more strategically focused and front-end orientated on issues that have been considered beyond the domain of traditional, technocentric and execution-orientated project management. These six implications are presented within the context of two forms of real estatecontext: that real estate which already exists and that real estate yet to becreated. While dominated by engagement with UK expertise, it is anticipated that the paper will be of interest to a global audience.
\end{abstract}

\section{Keywords}

Twenty first century real estate, project management's role, grand challenges, rethinking real estate, UN SDGs,

\footnotetext{
${ }^{1 *}$ The Bartlett Real Estate Institute, UCL, London WC1E 6BT, United Kingdom, andrew.edkins@ucl.ac.uk (Corresponding Author)

${ }^{2}$ The Bartlett Real Estate Institute, UCL, London WC1E 6BT, United Kingdom

${ }^{3}$ The Bartlett Real Estate Institute, UCL, London WC1E 6BT, United Kingdom

${ }^{4}$ Colorado State University, Fort Collins CO 80523, Colorado
}

Engineering Project Organization Journal

(C) 2021 Engineering Project Organization Society

www.epossociety.org 


\section{Introduction}

The 20th century heralded the creation of many forms of specialisation within the built environment, from the development of specialist sectors, such as data centre construction to the emergence of specialist roles, such as façade engineers. This was an evolutionary form of diversification and specialisation that arose from the industrial revolution and followed the observations and arguments made by the seminal economist Adam Smith (Smith, 1776). However, as this paper will outline, the nature of the challenges faced by us as a species, bound as we are to this planet we inhabit, requires us to find ways to learn about new issues, develop new skills and work in new areas if we are to both survive and thrive. As a point of departure, the paper considers the value proposition as presented by the broad area of real estate. To initialise this, reference is made to two areas of growing significance. The first is the rise of the concept of the 'Grand Challenge' and the second is the significance of the United Nations Sustainable Development Goals. The paper then explores how these challenges and issues can be considered in separable areas that allow insight and potential action. To do this, the paper introduces a series of eight real estate related themes that have resulted from an extensive identification exercise. These eight themes are considered as pertinent to the real estate sector in the 21 st century. Within these eight themes, the paper then examines the potential role of one of the key actors involved in the creation, adaptation and removal of real estate - the project manager.

Project management is considered as it provides a discrete and formalised approach for the delivery of important and specified change that is typically delivered through the creation and production of new services, products, artefacts and entities. Whether we look to leaders in academe, such as Morris (Morris, 2013), Turner (Turner, 2016), Levitt (Scott et al., 2011), Pinto (Pinto and Slevin, 1988), Winch (Winch, 2010), Söderlund (Söderlund, 2011), and Shenhar (Shenhar and Dvir, 2007), or professional bodies (eg, Project Management Institute (PMI), Association for Project Management (APM)), International Project Management Association (IPMA) or governmental and international organisations (eg, various governmental departments across the US, UK, Canada, Australia, World Bank, UN or EU, such as Treasury departments, defence departments, official audit agencies), the focus on project management and its essential role in project delivery continues to grow. The world of project (and programme and portfolio) management and the projects and programmes being overseen, continue to increase in complexity and gain greater importance to us socially, economically and environmentally. Project management continues to expand as a field of practice and scholarly study as an increasing number of domains engage project management principles and practices, for example, the expansion of project management into information technology (IT) and information systems (IS) and the creative sector (Hartman and Ashrafi, 2002; Marcella and Rowley, 2015). With the development of new forms of technology in many areas, we can expect a similar evolutionary step in project management, for example, as we continue to unlock the science of the genome and move into the new area of synthetic biology (Linshiz et al., 2012).

The creation and functioning of the built environment continue to utilise the skills and competences of project management to the point today where there are specialist project managers focussed on sectors such as 'property', 'construction' and 'infrastructure'. However, these sector-defining terms are somewhat loose in their use and their precise definition is not always clear, obvious or agreed. Specifically, property and real estate are words that, to many, may have similar meaning and have geo-linguistic preferences. However, a critical common link in these various terms is their connection to and association with land (Ellickson, 1993).

While there may be a degree of variation as to the remit of the terms mentioned above, two immutable issues surround the concept of the "built environment'. First, these areas of human activity (broadly the creation and operation of many forms of buildings and similar outputs of the construction and civil engineering sectors - typically fixed within or on the land and used for at least a single purpose) are vitally important to us; second, all 
these products that comprise what we recognise as our built environment have both existing and new sets of forces affecting them, pressures upon them and expectations of them. If we accept the UN's Sustainable Development Goals (SDG) then we have more to do to be able to evaluate and measure other forms of value, particularly social and environmental, that arise or are derived from real estate. This argument is supported by the widespread adoption of 'ESG' consideration, assessment and metrics across both sectors and forms of asset. Environmental, Social and Governance (ESG) concerns have been introduced into the decision-making and performance assessment of both organisations and assets held, as illustrated by the plethora of methodologies and tools for ESG assessment (Temple-West, 2019) and the research of Lokuwaduge \& Heenetigala that considered ESG issues on the extractive industries in Australia (Lokuwaduge and Heenetigala, 2017).

We have set out the overall changes and challenges acting upon real estate; the next section will review examples of the literature relevant to argue the position being taken that emerging challenges require a refocusing and redefining of project management within the real estate domain. Following this, there will be consideration of the philosophical position taken by the paper and the method used. Then the findings of the research will be presented and discussed, before the paper concludes with the reflective assessment of the utility of the research undertaking and the suggested next steps.

\section{Review of the Literature}

\section{The Grand Challenge Context}

This paper is about the role of project management within what is considered as real estate in an era of significant change or 'Grand Challenges'. Many organisations have adopted phrasing similar to grand challenges as illustrated in Table 1, which shows the results of a UK-based snapshot internet search of the term 'Grand Challenge' using the Google search engine and carried out in the third quarter of 2020. The global pandemic of the Covid-19 Coronavirus experienced in 2020 has required immediate action and changed both priorities and perspectives and is clearly the most pressing of grand challenges. However, preceding the Covid-19 pandemic there was a recognition of the concerns about the climate with the introduction of the term 'climate emergency' triggered by the IPCC report on climate change (IPCC, 2018). From Table 1, which is acknowledged as having a UK bias, one finds a diverse range of organisations that are concerned about such global and fundamental issues and concerns. Having noted the variety and scale of the challenges as featured in Table 1, to tackle these challenges will require the development of strategies and policies that will bring about change. Executing some of these strategies and policies will involve creating individual or collections of projects and programmes (Morgan et al., 2008). If we do seek to find the solutions and changes through the use of projects and programmes, then this will create new opportunities for those engaged in the area of project management.

The argument for the application of the clearly distinct management discipline of 'project management' has been deemed necessary for projects to be successful (Baker et al., 1997; Munns and Bjeirmi, 1996). This will involve the combination of project managerial skillsets with a variety of tools and techniques that together can be expected to deliver projects more successfully than any other way (Morris and Pinto, 2004; Morris et al., 2012; Turner, 2016).

\section{Defining Real Estate}

Having established the range and scale of changes and challenges that our species and planet face and then recognised both the importance and relevance of project management, we now turn to the realm of the built environment and real estate. The built environment is a term used to identify a form of environment that mankind has created and is thus an adaptation of the base natural environment (Kaklauskas and Gudauskas, 2016). The term 'real estate' is closely associated with the built environment and is a term more popular in some countries than others, but is typically used to define discrete industrial and economic sectors. The OED defines real estate as: 


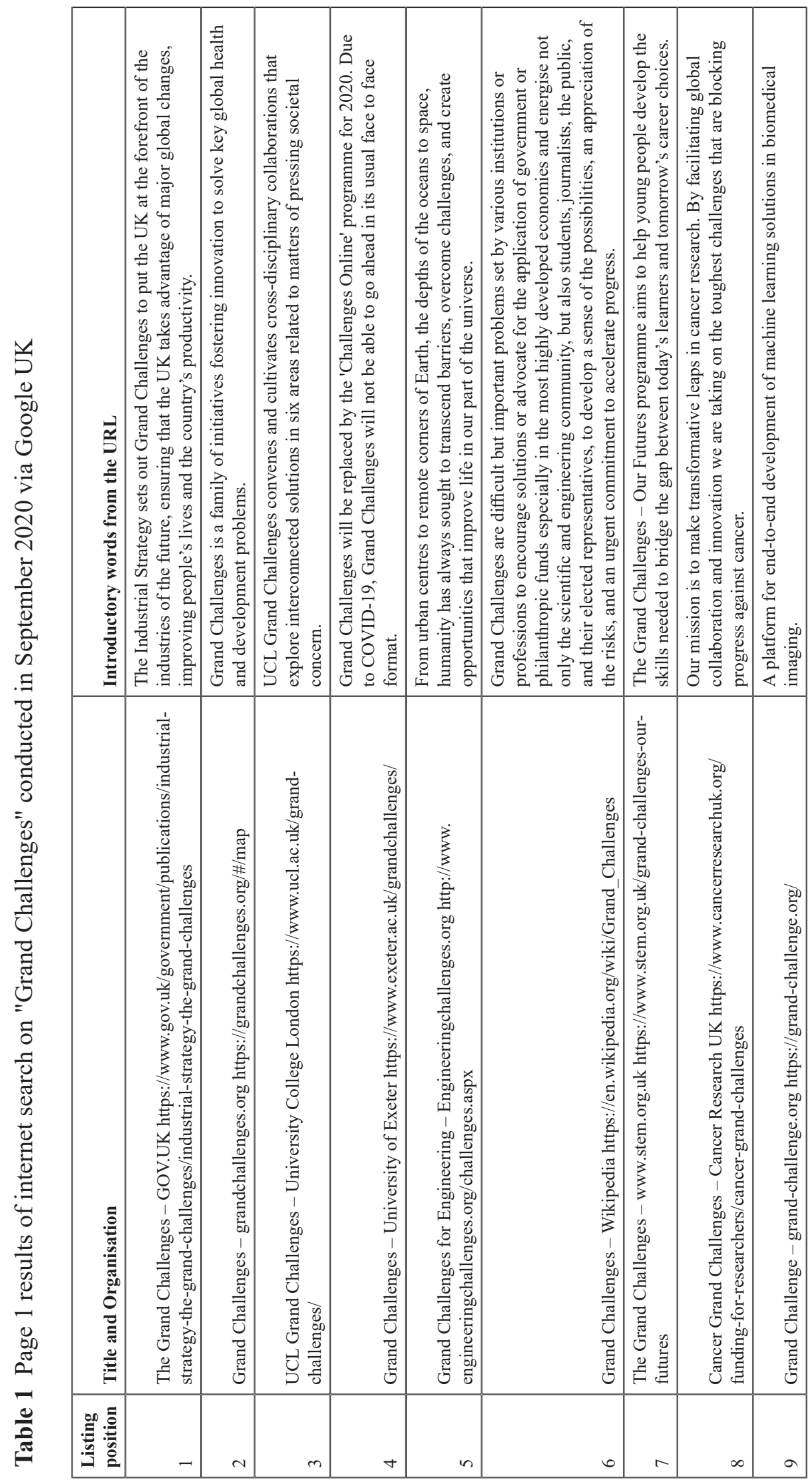

Engineering Project Organization Journal

(C) 2021 Engineering Project Organization Society www.epossociety.org 
"Propertyconsisting ofland and the buildings on it, along with its natural resources such as crops, minerals, or water"(Oxford English Dictionary, 2018).

Whilst many academics have used the term 'real estate' in books and various learnt papers, it is somewhat surprising that there are so few definitions of what the term is referring to. Indeed, such is its prevalence and widespread use, that it is assumed that the reader recognises real estate to be considering elements such as property or indeed subsets within property, such as residential, commercial or industrial. According to an article by (LaDue, 2016) that references the MerriamWebster dictionary, real estate is property that is fixed and located to land and the term was first used in the mid-17th century. LaDue suggests this was 1666 (the year of the Great Fire of London), but the online version of Merriam-Webster (accessed November 2020) indicates the first reference was in 1642.

To make clearer the term real estate's significance, an appreciation of what comprises it is needed and in this regard the contribution on Amadeo is useful as it identifies four 'types' of real estate: residential real estate, commercial real estate, industrial real estate and land (Amadeo, 2020).

Chen (2020), writing on the website Investopedia, follows this line, with his definition consisting of:

"Real estate is the land along with any permanent improvements attached to the land, whether natural or man-made-including water, trees, minerals, buildings, homes, fences, and bridges. Real estate is a form of real property. It differs from personal property, which are things not permanently attached to the land, such as vehicles, boats, jewelry, furniture, and farm equipment."

Source: https://www.investopedia.com/terms/ r/realestate.asp

\section{The Value of Real Estate}

Given this breadth of what is defined as real estate, it is inevitable that it is one of the most significant forms of economic and financial wealth, which is a key form of value.
This wealth arises from the simple premise that land is capable of being owned and that this land has tradeable (ie, exchange) value. If from this land you are able to derive enhanced value, maybe through the minerals that lie under it, the crops that be produced from it, or the real estate artefacts (ie, buildings and similar) that you can build under, on or over it, then land and land-based items can become highly valued financial assets. To illustrate this, the financial value of global real estate was estimated in 2017 to be US\$280.6 trillion (Savills, 2017), around 3.5 times the output of the global economy - the estimated Gross Domestic Product of the world in 2017 being US\$87.698 trillion (World Bank, 2020).

The financial value of real estate is linked to the macro economic environment at various levels, from the local/regional to the national/global that influence the real estate markets (Case et al., 2000). Case et al propose that this same real estate has substantial value that is less tangible but arguably has impacts that span from our individual health and wellbeing, through the future of many forms of organisation, to the future performance of our planet's ecosystem. Identifying and appraising the variety of value-types is far from easy at the level of the individual real estate asset (Boyd, 2006). Many commentators on the issue of real estate value argue that the exercise of real estate valuation is as much an art as a science (Crosby et al., 1998; Kummerow, 2003). The question of value in the context of real estate is one of value 'to whom?' as well as the more conventional questions such as 'over what period of time?' and the more technocratic 'at what discount rate or capitalisation rate?'. These questions and concerns have been considered in various ways, from the creation of new approaches such as 'Responsible Property Investment (RPI) (Pivo and McNamara, 2005), which led to the establishment and production of reports from dedicated working groups within the United Nations (UNEP FI Property Working Group, 2018). These developments can be seen as part of the wider spread changing of viewpoint and behaviour related to the growing adoption of ESG factors. All these shifts are principally aligned to the UN's SDGs. 
This varying appreciation of value is something that project managers have had to deal with as they are tasked with delivering a 'valuable' project for whomever commissions them. But in order to ensure that value is delivered, tools, techniques and indeed expertise have been developed for use in project management in the form of value management (Kelly and Male, 2003), value engineering (Dell'Isola, 1966) and benefits management (Ward and Daniel, 2006).

Two examples where value that relates to both project management and real estate is already established as essential are reputation and health and safety. In the latter, it was historically accepted that in the pursuit of some forms of project - such as major construction and civil engineering - lives would be lost (see, for example, the case of the Aswan High Dam in (Mossallam, 2014)). Over time we, as civilised societies, have become increasingly intolerant to the loss of life in the name of projects, and now there are many laws, regulations and standards that are enforced to ensure the health and safety (H\&S) of project operatives (Langford et al., 2000; Lingard and Rowlinson, 2004). Thus, the value of H\&S in terms of project performance has risen and is now, for an increasing number of project players, immutable. ${ }^{1}$ The second example is that of the reputation of the client which may be judged through their projects. Clearly this then links back to the first example, but it goes well beyond the health and safety performance. This is especially true for governments operating in democracies where there is a free and independent media. Here, government projects must be seen to be conducted fairly and with appropriate levels of transparency. This can result in many areas of value being raised for consideration and inclusion, such as local job creation, minimal environmental disruption and mitigation, or even compensation for those affected by the project works - including the award of contracts (Global Construction Review, 2019).

\footnotetext{
${ }^{1}$ See, for example, the approach taken by the Francebased multinational corporation Vinci with its 'Safety First': https://www.vinci-construction-projets.com/ en/our-commitments/our-safety-policy/ (accessed September 2020).
}

The value drivers that are affecting both real estate and project management are tightly coupled as it is through the application or deployment of project management that real estate is first developed, then adapted and repurposed as buildings and structures are periodically demolished, removed and rebuilt, and as uses change. These divergent and emergent value drivers and domains are, this paper proposes, areas where we need increased awareness and a new mind-set, along with supporting methods, tools and techniques if we are to deliver against these increasing value expectations. This paper therefore follows in the spirit and the principles of strategic and holistic thinking as presented by the corpus of work that comprises the 'Management of Projects' (MoP) as championed by Peter Morris (Morris, 2013).

\section{Establishing the Research Questions}

Having reviewed the wider literature, there is the need to develop a set of tractable research questions. To do this, reference is first made to the United Nations SDGs as considered within the context of real estate. The 17 SDGs are presented in Table 2 along with both real estate related comments and emergent areas for real estate consideration.

Table 2 demonstrates how real estate can and does relate to all 17 SDGs. Within these Goals there are two principal concerns: those relating to people in some form (SDGs 1,2,3,4,5,6,7,8,9,10,12,16,17) and those relating to our natural environment (2, $6,7,13,14,15)$. Further review, as shown in Table 2 column three (Emergent Topics for Real Estate consideration), provides a list of topics offering the opportunity for further focus on issues such as: the need for communities (formal and informal) to have more of a role in the creation and operation of real estate; the need for more and improved healthcare and education; and the importance of infrastructural services. To address all these SDGs will require many areas of change, with an expectation that technological development will provide some of the solution, suggested by the words such as 'clean' (SDG $6 \&$ 7) 'innovation' (SDG 9) and even 'sustainable' and 'responsible' (SDGs 11, 12). The UN's SDGs 
Table 2 The United Nations 17 Sustainable Development Goals in the context of Real Estate

\begin{tabular}{|c|c|c|}
\hline $\begin{array}{l}\text { United Nation Sustainable } \\
\text { Goal }\end{array}$ & Real Estate related comment & $\begin{array}{l}\text { Emergent Topics for Real Estate } \\
\text { consideration }\end{array}$ \\
\hline GOAL 1: No Poverty & $\begin{array}{l}\text { The poorest will have the fewest property } \\
\text { or land rights, agency or control over the } \\
\text { space they occupy - hence referring to the } \\
\text { 'homeless'. }\end{array}$ & $\begin{array}{l}\text { Provision of housing and its } \\
\text { affordability } \\
\text { and most deprived }\end{array}$ \\
\hline GOAL 2: Zero Hunger & Agricultural land is real estate & $\begin{array}{l}\text { Land is the fundamental } \\
\text { unit of production and needs to } \\
\text { be made resilient }\end{array}$ \\
\hline $\begin{array}{l}\text { GOAL 3: Good Health and } \\
\text { Well-being }\end{array}$ & $\begin{array}{l}\text { Healthcare buildings and related facilities } \\
\text { are needed }\end{array}$ & $\begin{array}{l}\text { - Healthcare related build- } \\
\text { ings }\end{array}$ \\
\hline GOAL 4: Quality Education & $\begin{array}{l}\text { Education buildings and related facilities are } \\
\text { needed }\end{array}$ & - Education related buildings \\
\hline GOAL 5: Gender Equality & $\begin{array}{l}\text { Traditional gender roles are closely related } \\
\text { to the use and occupation of real estate (eg, } \\
\text { home-based v public roles) }\end{array}$ & $\begin{array}{l}\text { - Engagement with all com- } \\
\text { munity voices }\end{array}$ \\
\hline $\begin{array}{l}\text { GOAL 6: Clean Water and } \\
\text { Sanitation }\end{array}$ & $\begin{array}{l}\text { Infrastructural utilities and the land they } \\
\text { occupy are part of real estate. Land value is } \\
\text { normally increased when these are present. }\end{array}$ & $\begin{array}{l}\text { - Buildings need to connect } \\
\text { to the infrastructural utilities }\end{array}$ \\
\hline $\begin{array}{l}\text { GOAL 7: Affordable and } \\
\text { Clean Energy }\end{array}$ & $\begin{array}{l}\text { Land-based infrastructural utilities are part } \\
\text { of real estate. New and existing buildings } \\
\text { will need to adopt clean energy. The absence } \\
\text { of these utilities may devalue real estate } \\
\text { holdings. }\end{array}$ & $\begin{array}{l}\text { - Looking at the various } \\
\text { infrastructural services with the } \\
\text { recognition of the need for them } \\
\text { to adapt - to be resilient }\end{array}$ \\
\hline $\begin{array}{l}\text { GOAL 8: Decent Work and } \\
\text { Economic Growth }\end{array}$ & $\begin{array}{l}\text { Most economic activity is based on land so } \\
\text { local economies are closely bound up with } \\
\text { real estate. The cost and productivity of real } \\
\text { estate has an impact on local economies } \\
\text { and workforces who, in turn can shape the } \\
\text { returns and productivity of the real estate. It } \\
\text { may be termed a symbiotic relationship. }\end{array}$ & $\begin{array}{l}\text { - Need to make the places } \\
\text { where work takes place decent } \\
\text { and inclusive for all and for } \\
\text { prosperity to be achieved in a } \\
\text { sustainable and resilient way }\end{array}$ \\
\hline $\begin{array}{l}\text { GOAL 9: Industry, } \\
\text { Innovation and } \\
\text { Infrastructure }\end{array}$ & $\begin{array}{l}\text { As the majority of industry and } \\
\text { infrastructure is land-based, performance } \\
\text { and innovation related activities are all } \\
\text { closely linked to real estate }\end{array}$ & $\begin{array}{l}\text { The interfaces between } \\
\text { buildings and infrastructural } \\
\text { services } \\
\text { - The increasing role of digi- } \\
\text { tal technologies }\end{array}$ \\
\hline $\begin{array}{l}\text { GOAL 10: Reduced } \\
\text { Inequality }\end{array}$ & $\begin{array}{l}\text { Asset control and ownership are part of } \\
\text { the mechanisms which create, preserve } \\
\text { or exacerbate inequality. Real estate (an } \\
\text { 'immovable asset') is therefore be part of } \\
\text { this process. }\end{array}$ & $\begin{array}{l}\text { - The need to involve more } \\
\text { in the process of creating and } \\
\text { enhancing real estate, especially } \\
\text { in those places that many people } \\
\text { live in and depend upon }\end{array}$ \\
\hline
\end{tabular}


Table 2 Continued

\begin{tabular}{|c|c|c|}
\hline $\begin{array}{l}\text { GOAL 11: Sustainable } \\
\text { Cities and Communities }\end{array}$ & $\begin{array}{l}\text { Cities are entirely formed of real estate and } \\
\text { the life of a city is closely linked to its real } \\
\text { estate industry regulation and practices. }\end{array}$ & $\begin{array}{l}\text { - The need to include the } \\
\text { many forms of community in the } \\
\text { creation and functioning of real } \\
\text { estate } \\
\text { - The need for all forms of } \\
\text { real estate to be more aware of } \\
\text { the impacts and consequences on } \\
\text { and to the natural environment }\end{array}$ \\
\hline $\begin{array}{l}\text { GOAL 12: Responsible } \\
\text { Consumption and } \\
\text { Production }\end{array}$ & $\begin{array}{l}\text { Both have clear links to real estate. Some } \\
\text { forms of communities and neighbourhoods, } \\
\text { for example, will have better capabilities and } \\
\text { outcomes than others. }\end{array}$ & $\begin{array}{l}\text { - Better places that enhance } \\
\text { communities can lead to enrich- } \\
\text { ment without the need for ever- } \\
\text { increasing levels of consumption. } \\
\text { Education and communication } \\
\text { will permit wiser decisions and } \\
\text { shift beliefs and behaviours }\end{array}$ \\
\hline GOAL 13: Climate Action & $\begin{array}{l}\text { Real estate contributes significantly to the } \\
\text { production of greenhouse gases through the } \\
\text { energy consumed in its creation, use and } \\
\text { disposal. }\end{array}$ & $\begin{array}{l}\text { - Real estate needs to change } \\
\text { in terms of what it is required to } \\
\text { do, both in the way it is created } \\
\text { and operated }\end{array}$ \\
\hline $\begin{array}{l}\text { GOAL 14: Life Below } \\
\text { Water }\end{array}$ & $\begin{array}{l}\text { The design and use of real estate have an } \\
\text { impact on water quality and Pollution levels, } \\
\text { impacting the broader ecosystem. }\end{array}$ & $\begin{array}{l}\text { Better created and oper- } \\
\text { ated infrastructure in terms of } \\
\text { water and Better education can } \\
\text { produce less harm to waterborne } \\
\text { life }\end{array}$ \\
\hline GOAL 15: Life on Land & $\begin{array}{l}\text { Real estate is intrinsically land based and its } \\
\text { creation and use replace natural habitats and } \\
\text { creates new ecosystems which affect all life } \\
\text { forms. }\end{array}$ & $\begin{array}{l}\text { - The built environment } \\
\text { represents much real estate and } \\
\text { this has normally required the } \\
\text { sacrifice of the natural environ- } \\
\text { ment. This has to change }\end{array}$ \\
\hline $\begin{array}{l}\text { GOAL 16: Peace and } \\
\text { Justice Strong Institutions }\end{array}$ & $\begin{array}{l}\text { Land sovereignty, ownership and control } \\
\text { are major components of international legal } \\
\text { systems. }\end{array}$ & $\begin{array}{l}\text { - Allowing a wider set } \\
\text { of voices into the real estate } \\
\text { decision-making will mitigate the } \\
\text { concerns that excluding them, as } \\
\text { evidenced through history, has } \\
\text { created }\end{array}$ \\
\hline $\begin{array}{l}\text { GOAL 17: Partnerships for } \\
\text { the Goals }\end{array}$ & $\begin{array}{l}\text { Single actors, owners, occupiers and players } \\
\text { cannot address issues of real estate alone } \\
\text { so partnerships are the way to achieve real } \\
\text { estate goals as well as Broader sustainability } \\
\text { goals. }\end{array}$ & $\begin{array}{l}\text { - The significant quantities of } \\
\text { real estate present and its pro- } \\
\text { found importance requires new } \\
\text { and fresh thinking that draws in } \\
\text { previously segmented and siloed } \\
\text { communities. }\end{array}$ \\
\hline
\end{tabular}

Source: adapted from United Nations, https://www.un.org/development/desa/disabilities/envision2030.html, accessed August 2020.

encourage us to re-conceptualise the forms of value we recognise and derive from real estate and this broad concept of value is fundamental to this paper. This paper recognises that we have developed clear methods for evaluating and monetising only some forms of value, while ignoring or marginalising others. We see this in the creation and operation of property markets and the monetisation of assets, but also in the real estate related generation of externalities, often negative or detrimental, such 
as congestion, pollution, disenfranchisement and inequality.

To provide coherence and focus to what is acknowledged as a wide area of consideration, this paper poses the following two research questions:

Research Question \#1: From the body of work comprising the Grand Challenges that includes the United Nations 17 Sustainable Development Goals, what are the key challenges that face 'real estate'?

Research Question \#2 What are the implications arising from RQ\#1 for those engaged in project management?

To assist in the consideration of RQ\#1 and RQ\#2, the paper draws on the triple bottom line approach as used in modern accounting and economics (Elkington, 1998). This considers that the principles of accounting can be applied to not just aspects of the economy, but also to society and the environment. By drawing on this 'triple' approach and adapting it through consideration of the UN's SDGs, we propose there are three areas of change that will present challenges to and of real estate and project management that link to people, our natural environment - and in particular mankind's impact on the climate - and the role of technology.

Through considering the range of major changes and challenges previously outlined and seeking to reduce to the fewest and grandest of these, three challenges are proposed:

- Demographic and Societal Change - our species numbers are increasing, many developed nations are seeing their populations ageing, and there is a worldwide trend of people moving and living in increasingly urban locations.

- Climate Change and Global Warming - the evidence of climate change is substantial and mankind's role in climate change is now substantially proven. In addition, we have habitat and biodiversity loss and extreme weather events

- Technological Change - The range and speed of technological developments, particularly in the area of digital technologies, is offering new opportunities as well as changing behaviours, decisions and actions.

These three forms of change are proposed as being recognised and non-contentious as there is an extensive literature base on each of them. This paper will seek to build from these three key change areas to propose a more granular set of specific challenges.

\section{Research Methods}

Philosophically, this paper aligns with the epistemological and ontological stance taken by those post-positivists that are now recognised as critical realists (Archer et al., 2013). This positioning lies at the heart of the assertion that within the concept of value there is 'intangible value', which is both latent and subjective, in all that is defined as being part of real estate. The critical realism rationale recognises that there is effectively an interface between the positivistic reality that leads to the laws that govern the natural sciences, with a more interpretist set of observations and perceptions that we apply. This then leads to the predication of the social sciences to the exploratory rather than the replicative form of enquiry (Tsang and Kwan, 1999). To illustrate this, consider the difference in value ascribed to a house as a residential real estate object or artefact. This 'value' may default to being the market-based assessment of its tradeable value and would be measured in a recognised currency. It is therefore an assessment of economic or financial value. In contrast, consider the value of providing this house providing a home. In some cases the home will be a place of happiness, contentment and safety and in others it may be the place of upset, fear and harm. Whilst the house is observable and appreciable as an artefact, the value of a 'home' is far more difficult to estimate and measure. This then explains the high investment many residential purchasers will make in search costs as there is the need to evaluate both the rational factors presented by the property as an artefact set in a location and the emotional appeal that is determined through engagement with the property (Kain and Quigley, 1970). The challenge of assessing and measuring 
such non-market-based value is a dilemma for those seeking positivistic clarity, but the argument drawn from critical realists is that the recognition of the acceptance of value as a concept that affects our reality is, itself, important. As more evidence from observation and other data-gathering takes this from a single perception of value to one that is recognised more widely and generally, so any postulated propositions take on the confidence of certainty. The Covid-19 pandemic in 2020 has demonstrated how our understanding of our reality can be challenged by a contagious virus that can affect different individuals in different ways. There is now an established view that speculates that there will be a 'new normal' as what we observe and what we know are different (Ochara, 2020).

The research methodology underpinning this paper is principally inductive in its approach and seeks to reasonably explore and expand rather than theorise and explain (Gioia et al., 2013). To provide the necessary focus, clarity and opportunities for action, the research sought to challenge the orthodoxy of the standard real estate thinking and practice, following Schön's approach in seeking to question the 'technical rationality' (Schön, 2001). This project began with research at the strategic level to look across specialist technical silos (Fear and Sandmann, 2016), whilst also following a form of arrangement aligned with development of engaged scholarship (Van de Ven, 2007). This was conceived within an extensive team of academics - including the authors of this paper - who are engaged with practitioners familiar with and expert in both real estate and project management. Two significant catalytic events encouraged and enabled this research and its approach to be adopted. The first was the commencement of the creation, in 2016, of an academic institute within a university setting that was seeking to investigate real estate in the context of the 21 st century and was designed to carry a mandate to work at the interface between academics, practitioners andpolicymakers to consider a wider view of real estate. The second was the appointment in 2018 to that institute of a globally recognised expert practitioner with a career spent researching real estate. This combination enabled the establishment of the premises as outlined in this paper and led to what can be best described as an emergent engagement exercise with a wide variety of real estate-related actors and parties over a three-year period. During that time, the research team had in excess of 200 'engagement events', ranging from small-scale meetings with one or two individuals, through to major events involving an audience of circa 200. The result of this emergence and development has been the identification of a set of eight emergent themes and frontier issues that the world of real estate can reasonably expect to need to address.

Reflecting the variety of changes and challenges to be faced and noting the inevitable bias that would result from the context of the research setting, the findings will next synthesise the arguments and examples that help summarise and illustrate the nature of the grand challenge. Following the presentation of the eight themes and frontier issues will be a section commenting on the insights and implications that are appropriate for those that are working in or interested in the field of project management as it relates to both real estate and the built environment.

\section{Findings}

The creation of the academic unit allowed many early and informal interactions between the authors and a wide range of others, including academics, senior representatives from industry and government as well as from the third sector. Given the nature of the context, there was considerable contact with international individuals and organisations, thus creating a more global perspective. From this range of early engagement exercises an initial 'long list' of factors and drivers that could reasonably be seen to significantly affect the 'world' of real estate was created as propositions. As conversations and engagement events progressed, so the various issues began to be refined and were concentrated into a reducing number of distinctly discernible themes, culminating in the emergence of eight separable themes. The objective of this stage of refinement and verification activity was to ensure that, through formal and informal review and reflective exercises on the content generated, the smallest number of separable, but non-discrete and indeed overlapping topic areas that could 
be used to 'reconsider' and 'rethink' real estate. This review, involving academics, practitioners and those involved in policy, critically factored in the need to cross-connect areas of expertise that have, over time, divided into professional, sub-sectoral and similar silos. This phase of the research, conducted over approximately a three-month period, resulted in the extrusion of a propositional set of eight topics or themes that could work both alone and in combination. This set was then further tested in a variety of settings, culminating in a validation exercise that was part of a major presentation at the launch event for the academic unit. Here, an invited audience comprising those familiar with and, often, in senior positions in the built environment, real estate, property and infrastructure sectors were presented with the eight 'themes' as they were termed. This audience $(n=180)$ comprised academics with differing expertise in the built environment, industry practitioners, representatives from the public sector and the third sector. The event had significant representation from senior leadership levels, including those at Chief Executive or Founder level.

Within the event, there was the opportunity for the audience to indicate their interest inthe active pursuit of one or more of the eight proposed themes. This was done through a simple voting exercise with audience members indicating their interest in any of the eight themes. This was a voluntary vote and individuals could vote more than once. A vote indicated a desire to be actively involved in further research, events, discussion and other types of engagement in relation to that theme. Each vote therefore meant more than just a passing interest in a theme and participants knew it would result in further contact and potential action. Circa $43 \%$ of those attending elected to vote, with circa $10 \%$ of those voting more than once. The voting exercise was an overt way of testing the voracity and credibility of the proposed themes, but to ensure that the proposed themes were both reasonable and adequate, additional informal feedback from attendees was gathered and this indicated neither dissent from the themes identified nor suggestions of important themes relevant to global real estate which had not been addressed under the eight, wide ranging and deliberately all-encompassing suggested headings.

The voting exercise served two purposes. First, it tested if all eight themes were seen as being reasonable. This test of reasonableness was straightforward - if any theme did not receive any indication of audience interest then it could be deemed as being irrelevant or unnecessary. The eight themes are listed below:

The second test was for relative popularity, or strength of interest, of each theme and this was achieved through a simple count of votes. The results of the second test are shown in Figure 1 below.

\begin{tabular}{|l|l|}
\hline 1. Infrastructure & 5. Resilience \\
Interface & 6. Digital Disruption \\
2. Beyond Placemaking & 7. Learning/Creative \\
3. Health and Wellbeing & Environments \\
4. Housing Accessibility & 8. Community Inclusion \\
\hline
\end{tabular}

As can be seen from Figure 1, the first test, that of the acceptability or reasonableness of the eight proposed themes, was passed as all themes received above $5 \%$ of the overall vote and with $10 \%$ of those voting indicating their interest in more than one theme - the two lowest scoring themes each receiving $8.9 \%$. The second test of interest/popularity is of some interest as it indicates the particular audience member's interest at that time - the two highest scoring themes being, first, 'Infrastructure Interface' (20.3\%) and second, 'Beyond Placemaking' (16.5\%). Subsequent to this major event, these eight themes have been presented and discussed and, to date, they have continued to prove to be both sufficient and appropriate to cover the range of issues that real estate is tackling and will face in the future. It is recognised that in different jurisdictions and over time these themes may well change, but at this time and in this context, these eight themes are presented with a solid provenance.

This paper will next outline seven of these themes with one, community inclusion, being explored in a little more detail as it captures the results of a subsequent 'deeper dive' specialist engagement activity. This deeper dive took the form of a half-day interactive presentation and 


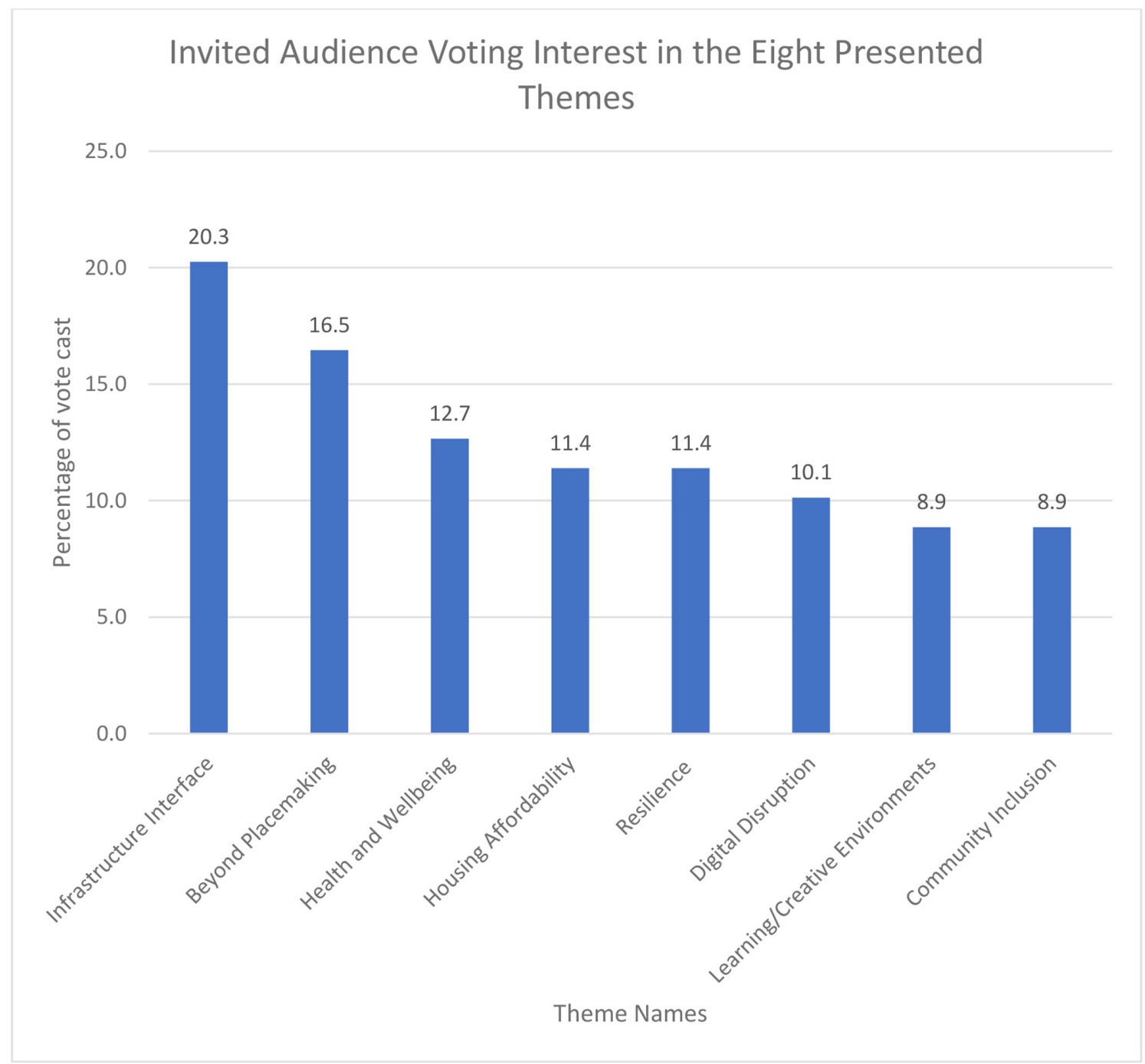

Figure 1 Votes cast to show interest in the eight themes

discussion event with an invited audience of circa 30 individuals actively involved or engaged with community inclusion. Again, the audience was composed of academics, industry practitioners, representatives from the public sector and those working in the third sector. These participants can be considered as expert in or familiar with this theme and the purpose was to look at the current challenges and future directions for this theme.

The findings of this research are presented presented in a structured way that considers each theme as a set of factors that are germane to real estate and which have clear implications for the project managers involved in the delivery of real estate. The principal implications for project management are then presented in a focussed section that follows the discussion of all eight themes.

\section{Infrastructure Interface}

Whilst technically all forms of infrastructure fixed to and, indeed, including useable land can be classed as real estate, in reality there are distinctions made in real estate to separate categories such as mining and quarrying from both agriculture and buildings and from all the variety of built elements that comprises 'infrastructure'. It is therefore reasonable to state that real estate and infrastructure are inextricably linked and both are 
manifestations of our built environment. Indeed, the modern urban world we have created makes the two fundamentally interwoven and interconnected. Whilst the definition of infrastructure would suggest that it needs to be in place first so that it can offer the necessary utility and service provision that is required of it, ${ }^{2}$ this is not always straightforward, easy or low cost as these infrastructural services and utilities need constant maintenance and upgrading.

Two forms of example of the challenge and role of infrastructure interfaces are offered. The first is the poor or absent infrastructure found in the informal settlements that can be found all over the world, including the favelas in South America, the shanty towns in southern Africa, and informal refugee and migrant camps now found in a variety of places such as Libya, Syria and the northern coast of France. In these cases, the infrastructure to provide sanitation (clean water and waste treatment) and power (principally in the form of stable electricity) has not been provided in a planned and structured way and in some cases is simply not present at all. The consequences are obvious to see, poor health and environmental degradation. The second case occurs in formalised built environment regimes and is where the real estate and infrastructure are out of balance. There are many examples of this, such as overloaded infrastructure as found with brownouts and blackouts in electricity supply, as well as chronic congestion on roads and overcrowding on trains. In other cases, existing real estate was only made viable by infrastructure (the case of Canary Wharf in London that was created through private investment, but which only succeeded as a viable commercial area when the Jubilee Line (part of the London public transport 'underground' system) was extended). An example of the reverse issue can be found in centrally planned economies, such as China, where its key infrastructure - such as main roads and railways - are installed well ahead of the anticipated real estate that is planned to follow, sometimes many years ahead.

\footnotetext{
${ }^{2}$ See for example the definition of infrastructure provided by the website Investopedia: https://www. investopedia.com/terms/i/infrastructure.asp (accessed December 2019).
}

Whether put in ahead or as a result, real estate and infrastructure have very many links and interfaces and these are set to exist as we move into new areas of infrastructure such as green infrastructure (Benedict and McMahon, 2002) and blue-green infrastructure (Wagner et al., 2013). This raises the need to consider the players and objectives involved in real estate and infrastructure - considered at both policy and market levels - as they are not treated as being synonymous and often aren't aligned. If we take the national level, infrastructure here is generally the domain of the centralised or federal government as many infrastructural services display key attributes of natural monopoly and the risk of market domination and exploitation. Even if it does not always provide it directly, the state and public sector will be expected to have the most powerful voice at the decision-making table. At the more regional, and now often city, level there will be those who increasingly recognise that optimal city functioning and performance is provided when the city functions as a total system, with the real estate and infrastructure working harmoniously, resulting in smooth flows of people, freight, money, data, energy and waste. Such optimality is not easy when there are distinct business models used, fragmentation of players and forms of ownership and different time horizons. In addition to this set of existing challenges there are potentially dramatic changes that can be feasibly considered in our near to mid-term future. A selection of these are the changes driven by shifts in focus within economics and finance - partially as a result of the Global Financial Crisis of 2008-9, the development and adoption of new forms of technology, the appreciation of the need for wider and better stakeholder involvement or the interest of those with increasing power such as politicians, regulators and even entire states and nations that recognise the importance and cost - in financial and political capital - of having cities that function optimally, in both effectiveness and efficiency terms. The current coronavirus pandemic has had a major impact on major cities as many city office workers have stayed away from city centres, with dramatic impact on the levels of economic activity that are reliant on the daily influx of office workers. As a result, there is much speculation as 
to what the 'new normal' will be for these cities and associated consideration of the consequences for the infrastructural provisioning for these cities (Sandbu, 2020).

\section{Beyond Placemaking}

The word 'placemaking' can be understood from the following quote from Aravot:

"Sense of place, which is the desired result of placemaking, was regarded as a human need, essential for wellbeing and feelings of safety, security and orientation, and a remedy against feelings of alienation and estrangement." (Aravot, 2002)

Places were and are made from the buildings and other structures we create. From the smallest of hamlets to the largest of global mega-cities, places play an important positive or negative role as the quote above makes clear. But how to do this well is far from clear and far from easy. Urban design has sought to be the focal point of expertise and urban designers study what makes a good, thriving and appreciated 'place' and what does the opposite. Moving to 'beyond placemaking' is a recognition that placemaking is a necessary objective, but a place is something that isn't just made, it needs ongoing care and attention - for reasons aligned to the forces and changes that have been outlined in the previous sections. In moving to the agenda of 'beyond placemaking' (alternatively this may be described as 'place-curating'), this emerging, or rather re-emerging, area of real estate practice and value creation is argued as a critical area for attention and study by those focussed on project, programme and portfolio management, be they academics, or practitioners focussed on policy. There is the need to recognise the multiple forces that will affect these places and push, pull and drive them in different and sometimes opposing directions. Take, for example, transport. Here, we need to consider getting to and from a place and moving around within it. This can lead to many interventions and in the 20th century this would have been increasingly dominated by using roadbased vehicles powered by internal combustion engines, together with other key types of transport such as air and rail travel. The popularity of the automobile has been global and car use increases with economic prosperity (Cervero, 2013). This then introduces the role of the road (here this word is selected to prioritise car and similar vehicle use) compared with that of the street (which is used to focus on the role of individual). This can be illustrated best through reference to specific places such as Los Angeles and other 'car dominated' metropolitan areas, versus Rome or Florence, where streets are for the flow of people. Where we have lots of people and lots of motorised vehicles we are increasingly finding conflict, whether this be on the grounds of safety, environmental consequences or simply reduction in overall appeal.

There willalways be a plethora of types of place, but when considering 'beyond placemaking' we need to understand the challenges and opportunities that prevail and are present for each place and seek to limit the negative factors that impair a place and promote those that enhance them. As an example of this concern, proposed changes to the UK planning laws in mid-2020 include the need for those proposing new construction of buildings to duly acknowledge and appreciate the importance of the vernacular design of the area. As noted in the consultation document:

"We are cutting red tape, but not standards.
This government doesn't want to just build
houses. We want a society that has re-
established powerful links between identity
and place, between our unmatchable
architectural heritage and the future,
between community and purpose. Our
reformed system places a higher regard on
quality, design and local vernacular than
ever before, and draws inspiration from
the idea of design codes and pattern books
that built Bath, Belgravia and Bournville.
Our guiding principle will be as Clough
Williams-Ellis said, to cherish the past,
adorn the present and build for the future."

Source: Foreword from the Secretary of State, https://www.gov.uk/government/consultations/ planning-for-the-future/planning-for-the-future, accessed August 2020 


\section{Health and Wellbeing}

The interplay between real estate in all its forms and our health and wellbeing, both individually and collectively, is well documented with many organisations such as Deloitte, UKGBC, International Well Building Institute, $M \& G$ and the publication Property Week having recorded activity in this area. Whilst these organisations and journal convey generalities of real estate's role and influence on our general health and wellbeing, there is also the vital and specific role played by healthcare facilities - those specialist and dedicated forms of real estate we know as our hospitals, specialist clinics and medical facilities, general practitioner and dental surgeries and the increasing number of other primary or similar first point of contact healthcare facilities that are embedded in our retail and community areas, such as pharmacies, opticians and audiologists. As concerns about health increasingly extend to include considerations about wellbeing, so we are observing a wider remit for the role of real estate in both health and wellbeing, including the design of workplaces as well as important roles for gyms, leisure centres and community halls, playing fields, parks, gardens and recreational grounds. These different forms of real estate offer a wide variety of services that assist the pursuit of good health and fitness and can play a remarkably important role in our physical, mental and social health.

This range and diversity demonstrates how our need for healthcare and wellbeing is expanding and increasing and this is mirrored in the variety of types of real estate that address these needs, everything from the highly expensive and complicated leading hospitals and medical campuses, through community embedded medical clinics and associated retail-based healthcare, to the wide variety of real estate offering wellbeing, including going outside to walk, to play or relax for example.

\section{Housing Affordability}

Housing is vital as it solves a fundamental need for shelter and safety. From this basic set of needs has evolved a wide variety of housing solutions. As housing is anchored to land, so land ownership and property rights have become important factors in the provision of housing, and our inherent need for housing, coupled with complex supply solutions, has led to some nations experiencing housing as a focus of financial investment, in extreme cases acting solely as a store of value. Like many other globally recognised places, London, UK is such a case where new residential real estate is not always provided for those with the greatest fundamental need. This includes not just the vulnerable, designated as 'homeless', but also keyworkers on lower levels of pay who are priced out of the accommodation market. For the most vulnerable the problem can be both acute and then chronic, as there may be few providers of new housing and a chronic under-supply. As urbanisation continues, so the demand for housing in urban areas will increase. If demand continues to outstrip supply then crises result. As we look to the future, we see that housing is likely to present new sets of challenges as at least three factors start to impact significantly. These are:

- Climate change: affecting internal heating and cooling (Mavrogianni et al., 2010) as well as coping with extreme weather events (Hales et al., 2007).

- Coping with changing demographics, especially a rise in the proportion of the population who are variously described as seniors or the elderly who will present a wide variety of needs from their homes (Agile Ageing Alliance, 2019).

- The costs of maintenance and facility management in large and often tall multioccupancy residential blocks. Here, the high cost of land and proven technology have allowed us to 'stack' in the form of tall towers of apartments. This is extremely land efficient, but it will raise the challenge in the future when large-scale repair and improvement works will be required.

\section{Resilience}

As noted in the earlier section on Beyond Placemaking, there is a need for constant monitoring and updating of the places that 
individual elements of real estate creates. This is a form of resilience which is more important than ever in the 21 st century as new forms of change occur and some rates of change increase. This is already illustrated by the impact of the rise in online shopping on retail real estate such as shops and shopping malls/centres (Dixon and Marston, 2002). To understand what resilience is in this context, consider when real estate resilience fails. Failure can manifest in many ways, from individual building's becoming obsolete (Thomsen and van der Flier, 2011) through to entire areas degenerating and falling into disuse for shorter or longer periods of time, such as the 'rust belt' in the US, the shipyards of the north-east of the UK and the abandoned residential developments on the coast of Spain following the Global Financial Crisis. In some situations, economic activity simply moves location, or technologies and trends may simply lead to obsolescence. These economic forces are expected to continue with globalisation, technology advances, or simply tastes changing. The consequences can endure for years or even decades, impacting on the lives and livelihoods of individuals, families and entire communities.

The 21st century will also have other profound forces, most notably climate change. This may fundamentally alter the way that we understand real estate in many locations, given its fixed nature. Real estate located in low-lying areas, including Lower Manhattan, Venice, the Maldives and Bangladesh, will be profoundly affected when water inundation created by extreme weather events and rising sea levels makes what may have been prime real estate now useless and without value. This was dramatically and tragically seen recently (March 2019) with Cyclone Idai, which killed, displaced and affected so many in Mozambique, Malawi and Zimbabwe. Whether it is extreme weather events, or changing external conditions, real estate will have to adapt. But it is more than simply considering the external operating environment that real estate will have to operate within. The built environment is a major contributor to greenhouse gas emissions. The UK Government's Department for the Environment, Food, Rural Affairs referenced research published in 2010 (The Royal Academy of Engineering, 2010) showing that $42 \%$ of the UK's carbon emissions arose from buildings, whereas a joint paper from CarbonAction2050 and the Chartered Institute of Building reported different research that showed that $47 \%$ of $\mathrm{CO}_{2}$ emissions were from the creation and operation of buildings (CIOB \& CarbonAction 2050, 2013).

Real estate (here we include elements of transport infrastructure) will also have to be resilient in dealing with changing demographics. This includes considering how many of 'us' there will be - so generating the need for more real estate, where we will be located and our age and range of needs. Dealing with this changing demography is going to place many pressures on real estate as it has to grow and adapt, in size, its form and function, as has been experienced in Japan as it has adjusted to an ageing population.

\section{Digital Disruption}

Real estate development is impacted by digital technologies, both existing technologies (eg, the internet) and the many nascent technologies, for example:

- Distributed Ledger Technologies, such as blockchain, which can work in conjunction with other new technologies such as Building Information Modelling and 'smart' regulations and contracts to generate new forms of value from real estate.

- 5G mobile phone connectivity and growing use of Wi-Fi, coupled with the far wider spread use of embedded sensors and monitoring devices to allow the development and dispersion of the Internet of Things and the potential for many forms of automation, including semi or fully autonomous vehicles, intelligent buildings and smart cities.

These, together with improved computing technologies, artificial intelligence and other forms of cognitive and quantum-based computing, are highly likely to lead to ever-smarter buildings and the realisation of 'smart cities' and change many of the relationships that we have with our real estate, including the relocation, redesign or even complete 
redundancy of some forms of real estate. There are also those technologies yet to be developed ("technological unknown unknowns'). This technological landscape is going to both increase in size and become more ingrained and fundamental to normal operations. The impact of this digital disruption of and to real estate is already widespread and substantial, as illustrated by the rise of internet shopping, leading to the debates about the future of shops, shopping malls/centres and retail districts (Grimsey, 2013). The impact of digital disruption is being felt in all the sub-sectors of real estate, with the rise of crossover elements of real estate: the coffee shops that are now touch-down workspaces for the mobile knowledge worker, the libraries that provide access to increasingly digital media, the deliberately isolated locations selected for data centres, many of these manifestations accelerated by the current Covid-19 pandemic. This all leads to opportunities for choice and flexibility and this has allowed new entrants, new business models and new locations to emerge.

\section{Learning Environments: Incorporating Our Need for Creativity}

The essential role of education is widely accepted and for centuries real estate has been created to accommodate its needs, including kindergartens for the very young and specialised training facilities for those in their latter years (Schuller and Watson, 2009). Education and training can play an important role throughout our lives and, with new forms of knowledge and technologies emerging, there is always an opportunity to study or learn new skills. Different forms of education real estate will be able to cater to our different requirements as we move through education and training as our life-stages progress. From the formal and distinct school and university building, into the more blended and informal as provided by employers, third parties and even as we study and learn from our homes and when on holiday/vacation. The implications for real estate are that there will be more people seeking to learn and develop - as a function of both growing population, increasing recognition of the improved life chances such education offers and the importance of lifelong learning driven by an increasingly dynamic employment market.
The Covid-19 pandemic has now shone a spotlight on the importance of schools, universities and other educational establishments for the socialisation and mental wellbeing of young people and the significance of physically attending schools and university has been highlighted through the experience of their enforced closure to restrict the spread of the Covid-19 virus. Whilst the disruption to education has led to cancellation and alteration to formal assessments such as traditional examination, there have been other consequences, such as the significant increase in incidents of eating disorders amongst young people. The importance of attending school and university inperson is highlighted in the following quote:

"Teachers and university staff often flag concerns about a young person's weight loss oreating habits. The closure of schools and university classes and move to online lessons has inevitably made this more difficult, coupled with the fact that teachers are already under enormous pressures because of trying to reorganise lessons, manage infection control and cope with reduced staff because of illness." Source: Royal College of Paediatrics and Child Health, 2020.

For those schools, colleges and universities that have remained open to deliverface-to-face education, the pathology of this virus is forcing a reappraisal of physical space and the human interactions which can take place within them. This calls into question the notion of how classrooms, lecture theatres and similar learning spaces deliver the function they have been designed to perform safely now that we have experienced this global pandemic. Fortunately, the various digitally based technologies are now sufficiently advanced and available to allow lessons to be delivered remotely. How the physical and digital provision of education will blend and settle is yet to be determined and may take years to fully resolve, but this recent experience has proven the vital importance of the role of educational real estate. This question as to how to adjust and transition the educational real estate to be suitable for both blended learning and potential infectious diseases is a good example of how project managers are faced with dilemmas with immediate and practical consequences 
and transparent democracies now, such as the UK, land and real estate ownership is traced back to far earlier times when power of control was vested in those with the ability to command and take claim. In many countries there are long-standing land rights that establish patterns of land, real estate or property ownership rights where there is concentration of power: military, political, economic, environmental, cultural or social. This can play out in ways that can cause inequality, hardship and frustration. As time has moved on, so there have been changes to this exclusive right to land and real estate, with more challenges to historic rules. One illustration is the change in UK law in 2000 introducing the 'right to roam' in England ${ }^{3}$ that allows citizens wider access to areas of land beyond the 'rights of way' as provided for by the UK's network of public footpaths and similar. This is explained in the official UK Government guidance:

"You can access some land across England without having to use paths - this land is known as 'open access land' or 'access land'.

Access land includes mountains, moors, heaths and downs that are privately owned. It also includes common land registered with the local council and some land around the England Coast Path.

Your right to access this land is called the 'right to roam', or 'freedom to roam'."

Source: https://www.gov.uk/right-of-wayopen-access-land/use-your-right-to-roamaccessed November 2020.

The recognition of the importance and value of community would appear to be growing in many parts of the world and in many areas of activity, from the more obvious 'local community' social activities through to communities organising themselves to act as formal lobbying or even delivery bodies, as with the case of Community Land Trust (Moore and

\footnotetext{
${ }^{3}$ For more details see: https://www.gov.uk/right-ofway-open-access-land/use-your-right-to-roam accessed August 2020.
} 
McKee, 2012). A sense of community is embedded in our sense of place and is evident in the feeling of collective security created by initiatives such as Neighbourhood Watch, through to the recognition of the cohesive importance of village shops/pubs/ churches as places of congregation, social interaction, shared identity and service access, through to the recognition of the city as not monolithic, but polycentric (Griffith, 1981).

In London, an example of a polycentric city (New London Architecture, 2017) in June 2017 there was a calamitous and desperate tragedy when a residential tower block - Grenfell Tower - caught alight and the building turned into an inferno. Seventy-two lives were lost and those who suffered, whether physically injured, mentally traumatised or physically relocated, were not the rich and powerful. These were individuals who largely rely on the State to assist them in some way, often involving receiving some form of financial aid or benefit. These individuals and families looked to Grenfell Tower as their home, but on the night of 14th June 2017 - and in front of the TV cameras - this tower turned into a flaming disaster. This is important as the subsequent story of Grenfell revealed how real estate decisions had not involved the community, indeed this was real estate that was done 'to' the occupiers and evidently not 'with' this community. Why? The formal Public Inquiry is still under way, so it is still the realm of speculation, but the answer may be found in the allocation of power at the institutional and organisational level. The individual occupiers were relatively powerless compared with the owners (public sector) and management organisation (a company formed by the Local Authority, the Royal Borough of Kensington and Chelsea, to run all the relevant Local Authority's residential stock).

The impact of the Grenfell Tower fire has been and continues to be fundamentally important at a societal, sectoral and institutional level, with the potential for new laws, new forms of regulation - and even new statutory bodies to oversee these potential new laws and regulations. There are also likely to be fundamental changes in policy and procedure, and all of these changes are separate from the possible court proceedings that may take place in both criminal and civil law. Of profound importance will be the recognition that the voices of the community concerned are not ignored, overlooked or dismissed when it comes to the places and spaces that these communities call their home.

At the expert forum held to explore the topic of 'Community Inclusion' from a UK perspective, the authors engaged with a variety of individuals who had direct involvement in this area of community engagement, involvement and inclusion. In synthesising the results of this expert discussion, the following key points idenitifed. First, that the presumption of inclusion of the community in the development of real estate is sometimes (possibly often) more of a 'tick-box' exercise and the 'community' is not included or indeed meaningfully engaged in the development process. The evidence of this is the widespread experience of designs being presented to communities for comment. This shows that the design was not influenced by the affected community, but rather presented to it. Second and building on this first point, it is a fallacy to assume 'a' or 'the' community exists as an identifiable and cohesive organisation. Real estate is location based, so the presumption may well expect that the existing residents or occupiers in the locale will be 'the community', but this group of individuals and organisations in the vicinity of the real estate proposal may have little other than their location in common - and thus we should be thinking of communities in the plural, many of which may not identify as a coherent community. This can manifest itself when a person 'speaks for' the community, but there are questions of whether this single voice is actually representative of all especially those who, for whatever reason, have not made their voices heard or their opinions public. The rise of digitally based social media may be giving more of a voice to those who have not had the confidence or ability to become involved, but equally it can act as amplifier for views that are not as widespread as may first appear to be the case. The last importanrt point raised related to the process for considering real estate proposals, in the UK this being the regulatory 'planning system', is one driven by strict protocols and rules (Department for Communities and Local Government, 2015). Where there are opportunities to undertake transformative real estate interventions, as in the 
cases of major regeneration, the planning process and those enacting it can find themselves unable to cope with such radical innovation and revert to a more traditionally acceptable solution - potentially thwarting visionary opportunities for betterment in pursuit of the safe and compliant 'acceptable' proposal.

The three points described above can be considered as a contribution to the extensive literature on stakeholder management as they illustrate the need for careful planning and strategizing. To consider the community a homogeneous unit with a single voice is too simplistic, as is to think that engagement with such a community (or more strictly communities) on a limited basis will lead to acceptance or success. These three points reinforce the need to consider shifting away from transactional engagement towards the transformational forms of engagement as proposed by Bowen et al in their extensive review of the extant literature in this area (Bowen et al., 2010).

\section{The Overall Implications for Project Management}

The eight themes explored and examined in the preceding sections are all linked, first to each other and second, they all relate to the UN's 17 SDGs as summarised in Table 2. Some of these linkages will be more obvious, direct and immediate, but many of the SDGs embody a mandate for change and therefore hold potential implications for those involved in project management.

And each of the these themes considered all have implications for those involved project management. the strategic level there is the need to recognise the opportunity and importance of becoming more involved at the earliest stages of project consideration. This is an area of focus that others such as Nobelius, Morris and Williams have considered, advocated and reviewed (Nobelius and Trygg, 2002)(Morris, 2013)(Williams et al., 2019). Abstracting from the points made the eight themes, the following implications are identified as being relevant for those involved project management.
The creation of real estate requires a project and, because of real estate's propensity to be substantialand capable of longevity, real estate can experience multiple further project phases as it is adapted, altered and ultimately dismantled, demolished or destroyed. The role of project management is vital, both in terms of responsibility and accountability for managing the change represented by these projects. This is not just in the technical coordination required to deliver the project but also, and increasingly, in the recognition of the strategic intervention that the project represents, a point argued by Morris (op cit). Indeed, the role of forging and shaping the project,both to meet the sponsor/client expectations of what the change will yield, as well as factoring in the themes presented above which, we contend, modern real estate projects will have to consider, requires both the recognition of the importance of the role to be taken and the sets of skills, competences and areas of knowledge that those in the position of project management will have to assimilate. This ranges across the terrain identified in the eight themes from a greater familiarisation of the shift of real estate sectors to embrace and embed digital technologies in the creation and operation of their projects, to those skills and competences needed for wider and richer communications and diplomatic challenges with an ever more sophisticated range of project stakeholders. From these eight themes, six principal implications for project management are proposed as being noteworthy and these are set within two broad types of real estate project as discussed below.

The first implication is the opportunity residing in, and therefore the importance of, project management and project manager involvement at the earliest stages of project consideration. The commitment of client/sponsor resources up-front, when matters are uncertain is, we acknowledge, at higher exposure to the costs of resources being committed, but it is an area of focus that others such as Nobelius, Morris and Williams have considered, advocated and reviewed (Nobelius and Trygg, 2002; Morris, 2013; Williams et al. (2019).

Second, uncertainty, or more concretely, the exposure to unexpected change and challenge that real estate-related projects are going to have to cope with in the foreseeable future, is portended 
by the consideration of the eight themes presented. Using the themes as factors for consideration for real estate related projects should drive broader thinking about how to accommodate a wider set of project outcomes, not only at the front end of real estate projects where the genesis of action on areas such as value identification and creation occur, but also to have regard and consideration for the broader context and longer-term consequences of each real estate element.

Building on the second impliction, the third is that those managing projects will also recognise that the increasing quantity of data available, coupled with the reducing cycle time for insight to be gathered from these data can lead, somewhat counterintuitively, to exacerbating levels of uncertainty and unpredictability. There are many different examples of us gaining greater understanding of how interconnected our world is, at a pace that is increasing. Examples include the strategic investments in the technology that will underpin energy supply, whether nuclear or renewable, fuel cell or battery. The recent global pandemic of Covid-19 has caused new levels of uncertainty in areas where there was previous confidence as the future of city centre, office-based working has been challenged, with views that range from reversion to previous norms of behaviour and activity, to those who argue that we will see a shift to a new paradigm of permanent home and 'blended'working for knowledge workers. These examples illustrate the changing data landscape that can lead to uncertainty about the future that impacts on the confidence needed to make key project decisions. This dynamic data landscape is one for the project manager to be cognisant of, but this is set within a broader knowledge context, which is also expanding. For example, in areas clearly related to real estate sectors, there is the growing recognition of the links between physical and mental health and our overall wellbeing, which is all contingent upon the health of our planet. Our understanding of how interconnected these issues are is now growing as new areas of science and technology generate more data and insight. Drawing upon these and more, we can improve our ability to face the challenges and opportunities of making all real estate work better for us whilst working compatibly and in sympathy with the natural environment to ensure a better future. Those involved in project management need to be aware of the expansion, richness and dynamism of knowledge and data and how they need to lead and managfe the challange to shape, adjust and deliver projects so as to accord with this.

The fourth point for project managers to consider is how to handle the shift from risk-based management to an uncertainty-based one. The emerging sources of uncertainty as noted previously, contrast to the established area of project risk management, because of, amongst other things, the lack of obvious precedent. Project management has a long history in managing risk as evidenced by its inclusion within both the bodies of knowledge of the two main project management professional bodies: the US's PMI and the UK's APM (Project Management Institute, 2017; Association for Project, M. \& Association of Project, M, 2012), but project management in an age of what may be considered as 'increasing dynamic uncertainty' will require new approaches that can deal with this dynamic uncertainty. The challenge of managing uncertainty is not a new subject and in the domain of project management there is an established knowledge base from which to draw, for example the academic work of Perminova (Perminova et al., 2008) and Nota (Nota and Aiello, 2014),

Fifth and directly associated with the preceding points, project management will have to adjust to an ever-growing list and diversity of stakeholders, it will need to have greater skills and competences in stakeholder recognition, involvement, and management. The recognition of the importance of stakeholder management is not new and there is much work on this, see for example the work of (Karlsen et al., 2008; Olander, 2007; Jepsen and Eskerod, 2009; Eskerod and Huemann, 2013). The review of the evidence gathered for these eight themes clearly establishes the opportunity for project management and project managers to play a key role in this area of identifying and engaging. The skillset of project managers will need to factor in the need for wider and better stakeholder engagement and communication as projects become of interest to more people and organisations. For those interested in the technocentric execution 
of projects there will be much to focus on, but for those project managers interested in the more strategic issues and factors involved in real estate, there is great opportunity to play a more important and influential role.

The sixth and final implication for those involved in future real estate project management relates to their education and training. How these project managers will prepare their skillsets and abilities for this new world of real estate is a further discussion and beyond the scope of this paper, but it is an important consideration for those involved in preparing these next generation professionals, whether they be in real estate or project management related organisations and institutions, as well as for those involved in educating and training in the project management profession and the varied world of real estate. What is critical is that project managers understand the combinations and permutations of these changes as they play out on each real estate project. It is the very degree of heterogeneity and sense of uniqueness that will continue to make real estate an extremely interesting and testing space for project management to work in.

Having briefly considered the new issues and challenges that project managers may face, it is worth also noting the different forms of real estate project that will need to be handled. Real estate is capable of having multiple projects enacted on it over its lifecycle. These can be reduced to two broad types of project and the impact of the eight themes presented will have distinct issues for project managers to factor into their thinking, planning and strategizing. Given the abundance of real estate already created, the first type of project is the intervention in the existing real estate asset base. These refurbishments, retrofits or change of use projects are widely used and range in scale from the very minor 'refresh' level, through to the major and invasive, such as stripping back to the structural frame or substantial demolition only reusing existing foundations. In the case of agricultural land, this could include the 'de-intensification' of the land - returning it to nature for biodiversity improvement, water or soil retention or carbon sequestration. These types of project can be seen as the more routine, in terms of the number of projects undertaken, as real estate assets endure. It is perfectly possible to alter real estate as and when its benefits start to diminish. Simple economics and financial appraisal, coupled with relevant and accessible technology, will dictate whether any change is considered and commenced, when and in what guise. Adjusting and adapting this existing real estate to be compatible, relevant and acceptable to the issues and factors that have been presented in the eight themes outlined in this paper represents a very substantial and a very challenging future for project management to tackle.

The second form of project is the real estate that has yet to be created and built. These are the new build projects that can take place on unbuilt land (so-called greenfield) or reusing land with a recent history of human-built structures (brownfield). With agrowing and changing population, greater use of more advanced technologies, and changing climatic and environmental conditions, more and different real estate will be needed - and located potentially everywhere - on and even off this planet. This real estate, to be built in the near or longer-term future, will have to cope with a set of circumstances and contexts that can be expected to be very different from what we have seen in the past.

\section{Conclusions and Recommendations}

The paper has sought to set out a new perspective on real estate and consider the implications for those involved in project management. It has adopted an engaged scholarship and critical realist approach involving extensive interaction with a wide variety of practitioners and other academics to identify relevant topics for consideration. The paper's primary purpose is to provoke discussion and debate about real estate's role and contribution in the 21 st century, the values that arise or derive from this real estate and what it will have to contend in future. Its contribution is to demonstrate real estate's profound importance as one of the foundations of modern societies and economies and with a critical climatic and environmental role. All this is overlaid with significant change and challenge resulting from a diversity of dynamic 
driving forces, which the paper presents under eight separable yet clearly interrelated themes. The paper's second purpose focuses on the role of one of the key disciplines involved in real estate - project management. The paper presents argument that the role of project management will be increasingly important and, in some aspects associated with strategic and front-end issues, pivotal. Synthesising the implications for project management and project managers across all eight of the themes presented indicates the need for project management to be orientated to earlier, more strategic and policy-orientated issues.

This portfolio of significant and substantial change has been presented here through a set of eight themed areas that reflect the contributions and views of a wide range of experts catalysed by the creation of a new real estate focussed academic institution that included an internationally recognised real estate expert. From a postulation that was developed into an initial proposition, the process of refinement, development, validation and verification has taken time, drawn in a wide range of viewpoints and has resulted in the eight themes that have been both presented and discussed. The last of the eight themes considered - community inclusion - illustrates the further development,refinement and enhancement process that each of these themes is capable of, as it reflects the summarised key additional contributions made from an expert forum workshop discussion. Others are encouraged to continue to have these forms of engagement activities to enhance, refine and progress this form of enquiry enquiryas they not open deepen the understanding, but critically, they identify the 'cross-connects' between one theme and others.

This paper absolutely does not seek to create eight new silos of academic investigation, policy development or practitioner focus, but rather to illustrate and highlight the issues that real estate faces in the 21st century and the degree of interconnectedness. Project management is one of the important elements involved in the creation, operation and alteration of real estate and this paper has focussed on the potential for project management to make significant contribution to the real estate that will be needed for the 21 st century.
The eight themes identified and presented are to be considered as a (but not the) valid and useful way of considering the challenges and issues that real estate faces. The paper does strive to highlight the need for more interconnectedness and further work in all forms of engagement, academic research and teaching, policy development and professional development and training. This is seen as a significant challenge for all these actors and organisations in the 21 st century as the 19th and 20 th centuries have seen the creation, separation and arguably strengthening of many silos in academe, policy and professional practice. Further research into finding new ways of collaborating and crossing the boundaries between specialisms is needed. Whether this is across areas of subject matter expertise or actors' roles, more dialogue, exploration, investigation and understanding are needed. The results of the research conducted here indicate the clear need for more cooperation among and between researchers, practitioners and policymakers if we are to transform the recognition and appreciation, arising from the eight themes considered, of the areas that need to be addressed into the actions that need to be taken. The recent pandemic that spread globally in 2020 has illustrated how such combined and coordinated working can lead to dramatic progress as vaccines have been researched, authorised, manufactured, distributed and dispensed with unprecedented speed. This paper seeks to be a contribution to the need for more interdisciplinary research and collaboration and part of its purpose is encourage others to create similar endeavours, whether these are physical spaces or digital, that seek to both push and cross boundaries. There is an inherent challenge in such undertakings as they require those who have been schooled in the doctrine of ever narrowing focus and expertise creation to work at, or beyond, their standard boundary limits. This may add to the call for more 'boundary spanners' (Richter et al., 2006) and a greater investment in boundary spanning research. Such developments are not going to be simple or quick, but this paper contributes to the argument that such boundary crossing is necessary. What appears to be increasingly clear is that it is only by drawing on far wider sources of knowledge, skills and experience that we will be able to solve 
the problems we will face and take advantage of the opportunities that will also arise.

\section{References}

Agile Ageing Alliance. (2019), "Neighbourhoods of the Future [online)", available at: https://www.agileageing.org/page/neighbourhoods-future/ [accessed March 2020].

Amadeo, K. (2020), "Real Estate, What It Is and How It Works: Four Types of Real Estate", The Balance, available at: https://www.thebalance.com/real-estate-what-it-is-and-how-it-works-3305882 [Accessed September 2020].

Aravot, I. (2002), "Back to phenomenological Placemaking", Journal of Urban Design, Vol. 7 No. 2, pp. 201-212. 10.1080/1357480022000012230

Archer, M., Bhaskar, R., Collier, A., Lawson, T. and Norrie, A. (2013), Critical realism: Essential readings. London: Routledge.

Association for Project, M. \& Association of Project, M. (2012), APM body of knowledge. 6th ed. ed. Princes Risborough: Association for Project Management.

Baker, B.N., Murphy, D.C. and Fisher, D. (1997), "Factors affecting project success", Project management handbook, pp. 902-919.

Benedict, M.A. and McMahon, E.T. (2002), "Green infrastructure: smart conservation for the 21st century", Renewable Resources Journal, Vol. 20 No. 3, pp. 12-17.

Bowen, F., Newenham-Kahindi, A. and Herremans, I. (2010), "When suits meet roots: the antecedents and consequences of community engagement strategy”, Journal of Business Ethics, Vol. 95 No. 2, pp. 297-318. 10.1007/s10551-009-0360-1

Boyd, T. (2006), "Can we assess the worth of environmental and social characteristics in investment property?" Proceedings of the Pacific Rim Real Estate Society.

Case, K.E., Glaeser, E.L. and Parker, J.A. (2000), "Real estate and the Macroeconomy", Brookings Papers on Economic Activity, Vol. 2000 No. 2, pp. 119-145. 10.1353/eca.2000.0011

Cervero, R.B. (2013), "Linking urban transport and land use in developing countries", Journal of Transport and Land Use, Vol. 6 No. 1, pp. 7-24. 10.5198/ jtlu.v6i1.425

Chen, J. (2020), "Real Estate, [online]”, Investopedia, available at: https://www.investopedia.com/terms/r/ realestate.asp [accessed December 2020].
CIOB \& CarbonAction 2050. (2013), Facts and Figures CarbonAction 2050.

Crosby, N., Lavers, A. and Murdoch, J. (1998), “Property valuation variation and the 'margin of error' in the UK", Journal of Property Research, Vol. 15 No. 4, pp. 305-330. 10.1080/095999198368310

Dell'Isola, A.J. (1966), "Value engineering in construction”, Civil Engineering, Vol. 36 No. No 9, pp. $58-61$.

Department for Communities and Local Government. (2015), "Plain English Guide to the Planning System", London, UK, available at: https://assets. publishing.service.gov.uk/government/uploads/ system/uploads/attachment_data/file/391694/Plain_ English_guide_to_the_planning_system.pdf [Accessed August, 2020].

Dixon, T. and Marston, A. (2002), "U.K. retail real estate and the effects of online Shopping", Journal of Urban Technology, Vol. 9 No. 3, pp. 19-47. 10.1080/1063073022000044279

Elkington, J. (1998), "Partnerships fromcannibals with forks: the triple bottom line of 21st-century business", Environmental Quality Management, Vol. 8 No. 1, pp. 37-51. 10.1002/tqem.3310080106

Ellickson, R.C. (1993), "Property in land", The Yale Law Journal, Vol. 102 No. 6/2, 1315. 1315-1397. 10.2307/796972

Eskerod, P. and Huemann, M. (2013), "Sustainable development and project stakeholder management: what standards say", International Journal of Managing Projects in Business, Vol. 6 No. 1 36-50. 10.1108/17538371311291017

Fear, F.A. and Sandmann, L.R. (2016), "The "New" Scholarship: Implications for Engagement and Extension", Journal of higher education outreach and engagement, Vol. 20, pp. 101-112.

Gioia, D.A., Corley, K.G. and Hamilton, A.L. (2013), "Seeking qualitative rigor in inductive research: notes on the Gioia methodology", Organizational research methods, Vol. 16 No. 1, pp. 15-31.

Global Construction Review. (2019), "Bechtel sues HS2 over award over award of $£ 1$ bn Old Oak Common contract, 2019", available at: http:/www.glob alconstructionreview.com/news/bechtel-sues-hs2over-award-1bn-old-oak-common-con/ [Accessed August 2020].

Griffith, D.A. (1981), "Evaluating the transformation from a monocentric to a polycentric City", The Professional Geographer, Vol. 33 No. 2, pp. 189-196. 10.1111/j.0033-0124.1981.00189.x

Grimsey, B. (2013), "The Grimsey Review: an alternative future for the high street", United Kingdom, B Grimsey;, available at: http://www.vanishinghigh-

Engineering Project Organization Journal

(C) 2021 Engineering Project Organization Society www.epossociety.org 
street.com/wp-content/uploads/2016/03/GrimseyReview04.092.pdf (Accessed March 2020).

Hales, S., Baker, M., Howden-Chapman, P., Menne, B., Woodruff, R. and Woodward, A. (2007), "Implications of global climate change for housing, human settlements and public health", Reviews on Environmental Health, Vol. 22 No. 4, 295. 10.1515/ REVEH.2007.22.4.295

Hartman, F. and Ashrafi, R.A. (2002), "Project management in the information systems and information technologies industries", Project Management Journal, Vol. 33 No. 3, pp. 5-15. 10.1177/875697280203300303

IPCC. (2018), "Special Report: Global Warming of $1.5^{\circ} \mathrm{C}$ [online]", available at: https://www.ipcc.ch/ sr15/ [accessed March 2020].

Jepsen, A.L. and Eskerod, P. (2009), "Stakeholder analysis in projects: challenges in using current guidelines in the real world", International Journal of Project Management, Vol. 27 No. 4, pp. 335-343. 10.1016/j.ijproman.2008.04.002

Kain, J.F. and Quigley, J.M. (1970), "Evaluating the quality of the residential environment", Environment and Planning A: Economy and Space, Vol. 2 No. 1, pp. 23-32. 10.1068/a020023

Kaklauskas, A. and Gudauskas, R. (2016), Intelligent decision-support systems and the Internet of Thingsthings for the smart built environment, Startstart-Upup CreationcreationElsevier. pp. 413-449.

Kelly, J. and Male, S. (2003), Value management in design and construction. London: Routledge.

Kummerow, M. (2003), Theory for real estate valuation: An alternative way to teach real estate price estimation methods. research monograph, Department of Land Economy and Valuation. vol. 29. Perth: Curtin University.

LaDue, J. (2016), “Where Did the Term 'Real Estate' Come From?" Yahoo., available at: https://finance. yahoo.com/news/where-did-term-real-estate103000184.html?guccounter=1\&guce_referrer= aHR0cHM6Ly93d3cuZ29vZ2xlLmNv̄bS8\&guce referrer_sig=AQAAAFf8YaJQdOgukhaqGFTY 785Qh1B40W5DHQGNHoa66u6pwCXfyA3w eY24ulEd569iZG37OqUMXR3qIcNDfMHIKukT FisIOgenq_Zr4kePqcXT3sA3pAvlxjFVVRODU9 9Qz1j9Lh4ufmGVkjmbhxqDrIick2soFCSf93QiTs ZLJWU2 [Accessed December 2020].

Langford, D., Rowlinson, S. and Sawacha, E. (2000), "Safety behaviour and safety management: its influence on the attitudes of workers in the UK construction industry", Engineering, Construction and Architectural Management, Vol. 7 No. 2, pp. 133-140. 10.1108/eb021138

Lingard, H. and Rowlinson, S. (2004), Occupational health and safety in construction project management. London: Routledge.

Linshiz, G., Goldberg, A., Konry, T. and Hillson, N.J. (2012), "The fusion of biology, computer science, and engineering: towards efficient and successful synthetic biology", Perspectives in Biology and Medicine, Vol. 55 No. 4, pp. 503-520. 10.1353/ pbm.2012.0044

Lokuwaduge, C.S.D.S. and Heenetigala, K. (2017), "Integrating environmental, social and governance (ESG) disclosure for a sustainable development: an Australian study", Business Strategy and the Environment, Vol. 26 No. 4, pp. 438-450. 10.1002/ bse. 1927

Marcella, M. and Rowley, S. (2015), “An exploration of the extent to which project management tools and techniques can be applied across creative industries through a study of their application in the fashion industry in the North East of Scotland", International Journal of Project Management, Vol. 33 No. 4, pp. 735-746. 10.1016/j.ijproman.2014.12.002

Mavrogianni, A., Davies, M., Wilkinson, P. and Pathan, A. (2010), "London housing and climate change: impact on comfort and health-preliminary results of a summer overheating study", Open House International, Vol. 35 No. 2, p. 49.

Moore, T. and McKee, K. (2012), "Empowering local communities? an international review of community land trusts", Housing Studies, Vol. 27 No. 2, pp. 280-290. 10.1080/02673037.2012.647306

Morgan, M., Malek, W.A. and Levitt, R.E. (2008), Executing your strategy. Boston, USA: Harvard Business School Press.

Morris, P.W., Pinto, J.K. and Söderlund, J. (2012), The Oxford handbook of project management. Oxford: Oxford University Press.

Morris, P.W.G. (2013), Reconstructing project management. Chichester, West Sussex, UK: John Wiley \& Sons Ltd.

Morris, P.W.G. and Pinto, J.K. (2004), The Wiley guide to managing projects. Hoboken NJ: Wiley.

Mossallam, A. (2014), "“We are the ones who made this dam 'High'!" A builders' history of the Aswan High Dam”, Water History, Vol. 6 No. 4, pp. 297-314. 10.1007/s12685-014-0114-6

Munns, A.K. and Bjeirmi, B.F. (1996), "The role of project management in achieving project success", International Journal of Project Management, Vol.

Engineering Project Organization Journal

(C) 2021 Engineering Project Organization Society www.epossociety.org 
14 No. 2, pp. 81-87. 10.1016/0263-7863(95)000577

New London Architecture. (2017), London's Towns: Shaping the polycentric city. London, UK: New London Architecture. 978-0-9956144-4-4.

Nobelius, D. and Trygg, L. (2002), "Stop chasing the Front End process - management of the early phases in product development projects", International Journal of Project Management, Vol. 20 No. 5, pp. 331-340. 10.1016/S02637863(01)00030-8

Nota, G. and Aiello, R. (2014), "Managing Uncertainty in Complex Projects". In: Faggini M, Parziale A, eds, Complexity in Economics: Cutting Edge Research. New Economic Windows. Cham: Springer.

Ochara, N.M. (2020), "Contextualizing the Outcomes of COVID-19 Global Response", available at: 10.2139/ssrn.3607899. 10.2139/ssrn.3607899

Olander, S. (2007), "Stakeholder impact analysis in construction project management", Construction Management and Economics, Vol. 25 No. 3, pp. 277-287. 10.1080/01446190600879125

Oxford English Dictionary. (2018), Real Estate. Oxford: Oxford University Press.

Perminova, O., Gustafsson, M. and Wikström, K. (2008), "Defining uncertainty in projects - a new perspective", International Journal of Project Management, Vol. 26 No. 1, pp. 73-79. 10.1016/j. ijproman.2007.08.005

Pinto, J.K. and Slevin, D.P. (1988), "Critical success factors across the project life cycle", Project Management Journal, Vol. 19 No. 3, pp. 67-75.

Pivo, G. and McNamara, P. (2005), "Responsible property investing", International Real Estate Review, Vol. 8 No. 1, pp. 128-143.

Project Management Institute. (2017), A guide to the project management body of knowledge (PMBOK guide) / Project Management Institute. Sixth edition ed. Newtown Square, PA: Project Management Institute.

Richter, A.W., West, M.A., van Dick, R. and Dawson, J.F. (2006), "Boundary Spanners' Identification, Intergroup Contact, and Effective Intergroup Relations", Academy of Management Journal, Vol. 49 No. 6, pp. 1252-1269. 10.5465/amj.2006.23478720

Sandbu, M. (2020), "The post-Covid future of cities is in our hands", Financial Times, London, available at: https://www.ft.com/content/35e19c77-6ce34305-97cc-9ad039734b0d [Accessed August 2020].

Schuller, T. and Watson, D. (2009), Learning through life. Leicester, UK: National Institute of Adult Continuing Education.
Scott, W.R., Levitt, R.E. and Orr, R.J. (2011), Global projects: institutional and political challenges. Cambridge, UK: Cambridge University Press.

Shenhar, A.J. and Dvir, D. (2007), Reinventing project management: the diamond approach to successful growth and innovation. Boston: Harvard Business Review Press.

Smith, A. (1776), "An inquiry into the nature and causes of the wealth of nations". The Glasgow edition of the works and correspondence of Adam Smith. vol. 2.

Savills, G.R. (2017), "8 things to know about global real estate value", available at: https://www.savills. com/impacts/economic-trends/8-things-you-needto-know-about-the-value-of-global-real-estate.html [Accessed August 2020].

Schön, D. (2001), From Technical Rationality to reflection-in-action, Supporting lifelong learning. Routledge: Abingdon, UK. pp. 50-71.

Söderlund, J. (2011), "Theoretical foundations of project management: Suggestions for a pluralistic understanding". In: Morris P. W. G, Pinto J. K, Söderlund J, eds, The Oxford Handbook of Project Management. Oxford: Oxford: Oxford University Press. pp. 37-64.

Temple-West, P. (2019), “Companies struggle to digest 'alphabet soup' of ESG arbiters, Financial Times. London, 6th October 2019 [Online]. Available online:", available at: https://www.ft.com/content/b9bdd50c-f669-3f9c-a5f4-c2cf531a35b5?emailId=5f5b $504 d 9556$ f80004510add\&segmentId $=$ a8 8 cbd2581d42-1845-7b82-00376a04c08f [Accessed August 2020].

Terje Karlsen, J., Græe, K. Jensvold Massaoud, M, Karlsen, J.T, Massaoud, M.J. (2008), "Building trust in project-stakeholder relationships", Baltic Journal of Management, Vol. 3 No. 1, pp. 7-22. $10.1108 / 17465260810844239$

The Royal Academy of Engineering. (2010), Engineering a low carbon built environment, The discipline of Building Engineering Physics. London: Engineering, RAE.

Thomsen, A. and van der Flier, K. (2011), "Understanding obsolescence: a conceptual model for buildings", Building Research \& Information, Vol. 39 No. 4, pp. 352-362. 10.1080/09613218.2011.576328

Tsang, E.W.K. and Kwan, K.-man. (1999), "Replication and theory development in organizational science: a critical realist perspective", Academy of Management Review, Vol. 24 No. 4, pp. 759-780. 10.5465/amr.1999.2553252 
Turner, R. (2016), Gower handbook of project management. Abingdon, UK: Routledge.

UNEP FI Property Working Group. (2018), Positive Impact Real Estate Investment Framework. Geneva, Switzerland: UNEP FI Property Working Group.

Van de Ven, A.H. (2007), Engaged scholarship: A guide for organizational and social research. Oxford: Oxford University Press.

Wagner, I., Krauze, K. and Zalewski, M. (2013), "Blue aspects of green infrastructure", Sustainable Development Applications, Vol. 4, pp. 145-155.

Ward, J. and Daniel, E. (2006), Benefits management: Delivering value from IS \& IT investments. Chichester: John Wiley \& Sons.
Williams, T., Vo, H., Samset, K. and Edkins, A. (2019), "The front-end of projects: a systematic literature review and structuring", Production Planning \& Control, Vol. 30 No. 14, pp. 1137-1169. 10.1080/09537287.2019.1594429

Winch, G.M. (2010), Managing construction projects. Hoboken, New Jersey, USA: John Wiley \& Sons.

World Bank. (2020), “The World Bank Data: GPD for the world, 2020. Available online:", available at: https://data.worldbank.org/indicator/NY.GDP. MKTP.CD?locations=1W [Accessed September 2020]. 